\title{
Genetic identification of Caribbean scleractinian coral recruits at the Flower Garden Banks and the Florida Keys
}

\author{
T. L. Shearer ${ }^{1,2, *}$, M. A. Coffroth ${ }^{2}$ \\ ${ }^{1}$ School of Biology, 310 Ferst Drive, Georgia Institute of Technology, Atlanta, Georgia 30332-0230, USA \\ ${ }^{2}$ Department of Biological Sciences, 109 Cooke Hall, University at Buffalo, Buffalo, New York 14260, USA
}

\begin{abstract}
Larval recruitment is the foundation for future coral populations. However, difficulties in accurately identifying the species of recruits confound our understanding of relationships between recruitment and adult populations. In addition, current methods of scleractinian coral recruit identification destroy the tissue, precluding molecular or genomic analysis of these samples. A genetic method was developed to distinguish among coral species commonly observed in Caribbean recruitment studies and to facilitate further genetic analysis of these samples. Application of this method to monitoring recruitment at the Flower Garden Banks (FGB) and the Florida Keys (FK) throughout the 2000 to 2001 and 2001 to 2002 reproductive seasons revealed almost exclusive recruitment from 2 brooding species Agaricia agaricites and Porites astreoides. Recruitment at the FGB was significantly higher than across the FK. Significant spatial variation in recruitment was observed within the FK, and although more recruits were observed in 2001 to 2002, there was no significant temporal variation. Differences in local adult populations (e.g. population sizes and live coral coverage), postsettlement mortality and general reef health were likely contributors to disparities in recruitment levels of brooding corals observed at these reefs.
\end{abstract}

KEY WORDS: Recruitment · Scleractinian coral · Caribbean · Genetic identification · COI · RFLP · Larval dispersal

Resale or republication not permitted without written consent of the publisher

\section{INTRODUCTION}

Larval recruitment - the settlement and survival of larvae - is a primary factor in determining the community structure of coral reefs, in replenishing reefs after disturbance, and in influencing the genetic structure of species across their geographic distribution. Despite the importance of larval recruitment in the maintenance of coral populations, there is relatively little empirical understanding of the mechanisms influencing larval supply, dispersal, transport and settlement. Thus, the complex interactions of factors associated with recruitment processes complicate efforts to determine the primary influences that shape the species composition of reef communities and genetic composition of reef populations.
The understanding of recruitment of scleractinian corals is further inhibited by the difficulty in accurate taxonomic identification. Newly settled corals $(<1 \mathrm{yr}$ since settlement), particularly those that are only a few millimeters in diameter, lack gross morphological features that often characterize adult colonies of the species (e.g. mounding and branching patterns). At a small size, coral recruits can often be identified only to the family level, and occasionally to genus, based on common skeletal characteristics (e.g. Harriott \& Fisk 1988, Fisk \& Harriott 1990, Harriott 1999, Baird \& Babcock 2000, Babcock et al. 2003, Glassom et al. 2004). To study species-specific phenomena such as connections between reefs via larval dispersal/transport, recruitment patterns, relationships between adult and juvenile abundance, and patterns in larval settle- 
ment and post-settlement mortality, reliable identification of newly settled recruits is essential. This paper describes a genetic method to distinguish species of coral genera commonly observed in Caribbean recruitment studies. This method was developed to determine the identity of recruits of target coral species for an on-going genetic study of reef connectivity (Shearer 2004, T. L. Shearer \& M. A. Coffroth unpubl. data). For such a study it is critical to include only the target species; however, morphological identification of recruits cannot reliably distinguish conspecifics, and so it was necessary to develop a method with greater specificity.

Current methods of identifying coral recruits require the removal of coral tissue to expose skeletal elements for identification (e.g. Fisk \& Harriott 1990, Harriott 1999, Baird \& Babcock 2000, Kojis \& Quinn 2001, Babcock et al. 2003). The destruction of coral tissue in this manner precludes genetic analysis of these samples, which could provide pertinent information on parent-
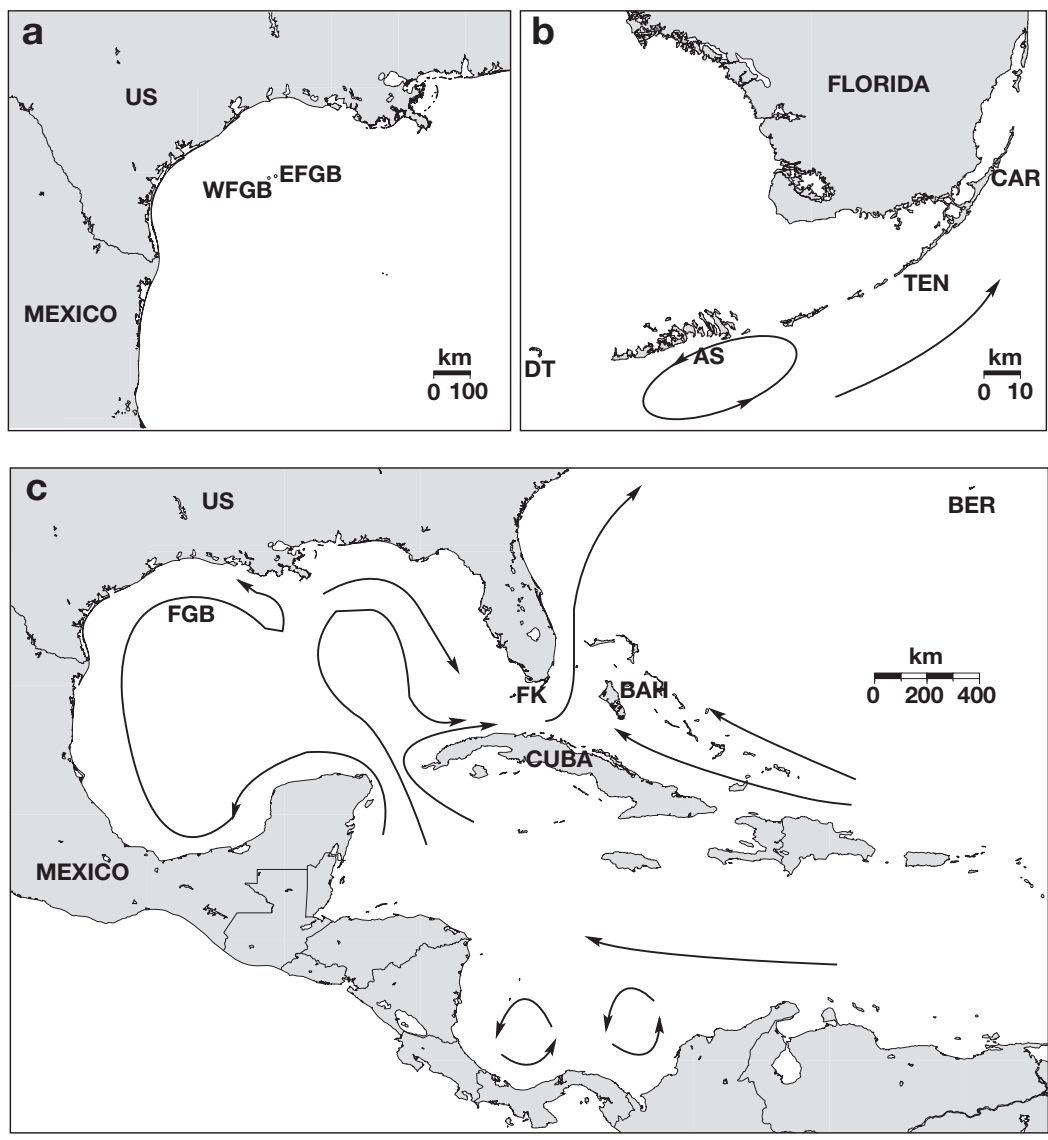

Fig. 1. Location of study sites at (a) the Flower Garden Banks (FGB) and (b) the Florida Keys (FK). Arrows indicate generalized circulation patterns influencing these reefs (from Rezak et al. 1985, Lee et al. 1994, Shulman \& Bermingham 1995, Ogden 1997). WFGB: West Flower Garden Bank, EFGB: East Flower Garden Bank, CAR: Carysfort Reef, TEN: Tennessee Reef, AS: American Shoal, DT: Dry Tortugas, BER: Bermuda, BAH: Bahamas age of new recruits, larval sources and genetic connections among reefs, ultimately achieving a fundamental understanding of recruitment processes. Application of molecular and genomics approaches to address ecological, evolutionary and management of marine organisms is becoming increasingly valuable (e.g. Palumbi 2003, Ryan \& Finnerty 2003, Sale \& Kritzer 2003, Shanks et al. 2003, Hofmann et al. 2005). Thus, preservation of coral recruit tissue for genetic analyses is desirable.

In this study, a genetic method of coral recruit identification was implemented to monitor recruitment patterns of scleractinian corals at the Flower Garden Banks (FGB) in the northwestern Gulf of Mexico and the Florida Keys (FK), including the Dry Tortugas (DT; Fig. 1), over 2 reproductive seasons (2000 to 2001 and 2001 to 2002). The reefs in these 2 geographic areas differ in many respects, including depth, seasonal temperature range, species diversity, coral cover and proximity to upstream reefs (Bright et al. 1984, Roberts 1997), which may contribute to differences in scleractinian recruitment patterns observed at these locations.

\section{MATERIALS AND METHODS}

Genetic method of species identification. Determining species-specific $\boldsymbol{R F L P}$ patterns: Sequence variation in the scleractinian mitochondrial cytochrome $c$ oxidase subunit 1 (COI) gene was used to determine the identity of coral recruits. Within Caribbean scleractinian species, sequences of this gene are highly conserved (reviewed in Shearer et al. 2002, Shearer 2004) with virtually no variation even among geographically distant samples (Snell 1997, Snell et al. 1998, Shearer 2004). Adults from 29 Caribbean coral species (Table 1) were collected and preserved either in a sodium chloride-saturated $20 \%$ dimethyl sulfoxide (DMSO) solution (Seutin et al. 1991), in $95 \%$ ethanol or frozen in liquid nitrogen. DNA was extracted following protocols described by Coffroth et al. (1992) or Shearer et al. (2005). PCR amplifications of a region of the COI gene were performed in $10 \mu \mathrm{l}$ volumes with 10 to $50 \mathrm{ng}$ genomic DNA, 1 unit Taq DNA polymerase and a final concentration of $0.2 \mathrm{mM}$ of each dNTP, 10 mM Tris-HCl (pH 8.3), 
Table 1. Classification and GenBank (www.ncbi.nlm.nih.gov/Genbank/) accession numbers for published mitochondrial cytochrome $c$ oxidase subunit 1 (COI) sequences of scleractinian corals used in this analysis. Species with identical superscripts have identical nucleotide sequences

\begin{tabular}{|c|c|c|}
\hline Taxon & Accession no. & Source \\
\hline \multicolumn{3}{|l|}{ Suborder Astrocoeniina } \\
\hline \multicolumn{3}{|l|}{ Family Acroporidae } \\
\hline Acropora cervicornis ${ }^{\mathrm{a}}$ & AY451340 & Shearer (2004) \\
\hline Acropora palmata ${ }^{\mathrm{a}}$ & AY451341-42 & Shearer (2004) \\
\hline \multicolumn{3}{|l|}{ Family Astrocoeniidae } \\
\hline Stephanocoenia michelini & AY451343 & Shearer (2004) \\
\hline \multicolumn{3}{|l|}{ Family Pocilloporidae } \\
\hline Madracis decactis & Not sequenced & \\
\hline \multicolumn{3}{|l|}{ Suborder Caryophyliina } \\
\hline \multicolumn{3}{|l|}{ Family Caryophyliidae } \\
\hline Eusmilia fastigiata & AY451345 & Shearer (2004) \\
\hline \multicolumn{3}{|l|}{ Suborder Faviina } \\
\hline \multicolumn{3}{|l|}{ Family Faviidae } \\
\hline Colpophyllia natans & AY451346-47 & Shearer (2004) \\
\hline Diploria labyrinthiformis & AY451348 & Shearer (2004) \\
\hline \multirow[t]{2}{*}{ Diploria strigosa } & AY451349 & Shearer (2004) \\
\hline & AF108716-17 & Snell (1997) \\
\hline Favia fragum & AY451350-51 & Shearer (2004) \\
\hline \multirow{2}{*}{ Montastraea annularis ${ }^{\mathrm{b}}$} & AY451352 & Shearer (2004) \\
\hline & AF013737 & Medina et al. (1999) \\
\hline \multirow[t]{4}{*}{ Montastraea cavernosa } & AY451353-56 & Shearer (2004) \\
\hline & AF108710-15 & Snell et al. (1998) \\
\hline & AF051094 & Snell et al. (1998) \\
\hline & AF013736 & Medina et al. (1999) \\
\hline \multirow[t]{2}{*}{ Montastraea faveolata ${ }^{\mathrm{b}}$} & AY451357 & Shearer (2004) \\
\hline & AF013738 & Medina et al. (1999) \\
\hline Montastraea franksi ${ }^{\mathrm{b}}$ & AY451358 & Shearer (2004) \\
\hline Solenastrea bournoni & AY451359 & Shearer (2004) \\
\hline \multicolumn{3}{|l|}{ Family Meandrinidae } \\
\hline Dichocoenia stokesi & AY451360 & Shearer (2004) \\
\hline Meandrina meandrites & AY451361-62 & Shearer (2004) \\
\hline \multicolumn{3}{|l|}{ Family Mussidae } \\
\hline Mussa angulosa ${ }^{\mathrm{c}}$ & AY451363 & Shearer (2004) \\
\hline Mycetophyllia aliciae ${ }^{\mathrm{c}}$ & AY451364 & Shearer (2004) \\
\hline \multicolumn{3}{|l|}{ Suborder Fungiina } \\
\hline \multicolumn{3}{|l|}{ Family Agariciidae } \\
\hline \multirow[t]{2}{*}{ Agaricia agaricites $^{\mathrm{d}}$} & AY451366-67 & Shearer (2004) \\
\hline & AF112120-21 & Snell (1997) \\
\hline Agaricia fragilis ${ }^{\mathrm{e}}$ & AY451368 & Shearer (2004) \\
\hline Agaricia lamarcki ${ }^{\mathrm{e}}$ & AY451369 & Shearer (2004) \\
\hline Agaricia tenuifolia $^{\mathrm{d}}$ & AY451370-72 & Shearer (2004) \\
\hline \multicolumn{3}{|l|}{ Family Poritidae } \\
\hline Porites astreoides & AY451374-79 & Shearer (2004) \\
\hline Porites branneri ${ }^{\mathrm{f}}$ & AY451380 & Shearer (2004) \\
\hline Porites divaricata ${ }^{\mathrm{f}}$ & AY451381 & Shearer (2004) \\
\hline Porites furcata ${ }^{\mathrm{f}}$ & AY451382 & Shearer (2004) \\
\hline Porites porites & AY451383-84 & Shearer (2004) \\
\hline \multicolumn{3}{|l|}{ Family Siderastreidae } \\
\hline Siderastrea radians & AY451385 & Shearer (2004) \\
\hline Siderastrea siderea & AY451386-87 & Shearer (2004) \\
\hline
\end{tabular}

705 base pair (bp) region of the mitochondrial COI gene. Thermal cycling protocol conditions consisted of a denaturing step of $2 \mathrm{~min}$ at $95^{\circ} \mathrm{C}$ followed by 40 cycles of $95^{\circ} \mathrm{C}$ for $30 \mathrm{~s}, 47^{\circ} \mathrm{C}$ for $90 \mathrm{~s}$ and $72^{\circ} \mathrm{C}$ for $90 \mathrm{~s}$. Successful amplification was confirmed by visualizing $1 \mu \mathrm{l}$ of the amplified products on $2.0 \%$ agarose gels stained with ethidium bromide.

The restriction enzymes HaeIII, MseI and TaqI (New England Biolabs) were used independently to digest the remaining PCR product of adult samples to identify species-specific restriction fragment length polymorphism (RFLP) patterns. Digestion conditions followed those recommended by the manufacturer with overnight incubation. Banding patterns for each species with each restriction enzyme were visualized on $2 \%$ agarose gels stained with ethidium bromide. DNA from zooxanthella cultures was amplified and digested with restriction enzymes to verify that patterns obtained from the PCR reaction were not of zooxanthella origin (Shearer et al. 2005). COI-RFLP patterns obtained from zooxanthellae were different from those of the corals (data not shown).

Identification of coral recruits: Immediately upon removal from the reef, recruits on recruitment plates were visually categorized into 3 morphological classes: Agaricia-like, Porites-like and Unidentified (including those too small to be identified). Recruits were further classified to species or to a group of species by comparing COIRFLP patterns with adults of various species. Recruits were removed from recruitment plates using a razor blade and preserved in a sodium chloridesaturated 20\% DMSO solution (Seutin et al. 1991). Protocols and conditions for DNA extraction, COI-PCR and restriction digestions of recruits were the same as in adult samples. COI-PCR

$50 \mathrm{mM} \mathrm{KCl}, 0.001 \%$ gelatin, $2.5 \mathrm{mM} \mathrm{MgCl}_{2}$, and $0.2 \mathrm{mM}$ of each primer. The forward primer was a shortened version of the Folmer et al. (1994) universal primer, LCOI1490: 5'-CAAATCATAAAGATATTGG3'. The reverse primer was the Folmer et al. (1994) universal primer, HCOI2198: 5'-TAAACTTCAGGGTGACCAAAAAATCA-3'. These primers amplified a digestions of recruits were run on a $2 \%$ agarose gel simultaneously with adults from various species (Fig. 2) to compare COI-RFLP patterns and classify recruits to species or group of possible species.

Recruitment arrays. In 2000 and 2001, arrays of unglazed ceramic plates $(15 \times 15 \times 1 \mathrm{~cm}$ each, grooved on 1 side) modified after Smith (1997) were placed at 


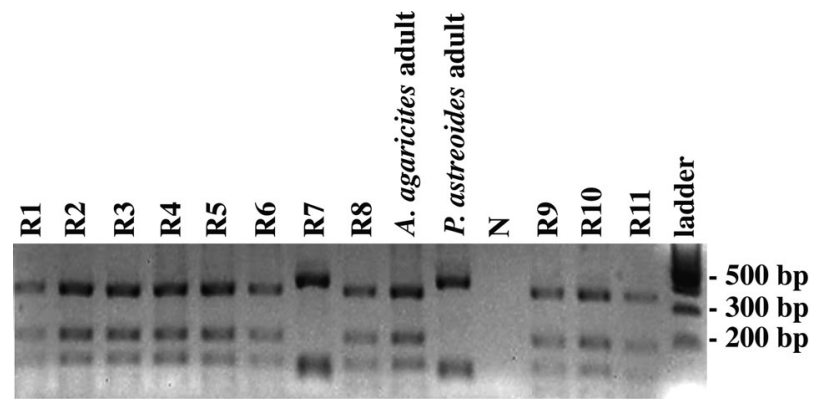

Fig. 2. Typical HaeIII digestion for identification of scleractinian recruits; Agaricia agaricites and Porites astreoides were adult standards. R1-6 \& R8-11: A. agaricites/A. tenuifolia recruits, R7: $P$. astreoides $/ P$. branneri/P. furcata/P. divaricata recruit, N: negative control, ladder: $100 \mathrm{bp}$ standard

the FGB (2 sites) and throughout the FK (5 sites; Fig. 1a,b, Table 2) to collect newly settled recruits to be used in a study of reef connectivity (Shearer 2004, Shearer \& Coffroth unpubl.). Three recruitment arrays were deployed at each site, for a total of 6 arrays at the Flower Garden Banks and 15 at the Florida Keys each year. Each array consisted of 12 recruitment plates (8 oriented horizontal and 4 vertical to the reef substrate with grooved side facing out; Fig. 3), providing $0.612 \mathrm{~m}^{2}$ of surface area per array as available substrate. Plates were attached to a PVC frame approximately $20 \mathrm{~cm}$ above the reef substrate. At each site, the arrays were secured to hard reef substrate using rebar and cement inside the PVC base, and placed within $5 \mathrm{~m}$ of each other. In the FK, data on juvenile (colonies $<4 \mathrm{~cm}^{2}$ ) abundance (D. Swanson pers. comm.) were available and used to select areas of high juvenile abundance in an attempt to maximize the number of recruits obtained. Similar data were not available for the FGB and recruitment arrays were deployed at a randomly selected area at each site.

Recruitment plates were deployed approximately $4 \mathrm{wk}$ prior to the expected reproduction of brooding coral species (for conditioning of plates) and sampled at least $8 \mathrm{wk}$ after the mass spawning of each year (Table 2). Recruits were collected from all surfaces of each plate and either the same plates were immediately returned to the reef (Oct-Nov 2000) or new plates were deployed (Feb-Mar 2001; Table 2). Due to the timing of the coral reproductive seasons (brooders: springsummer, broadcast spawners: late summer, reviewed in Richmond \& Hunter 1990, Szmant 1991, McGuire 1998), the vast majority of recruits were collected on the recruitment plates in the fall, several weeks to months after the reproductive season. Any recruits observed on plates collected in early 2001 were either overlooked during the fall 2000 recruit collection, or remained in the water column for longer periods of time, eventually settling after the fall 2000 recruit collection.

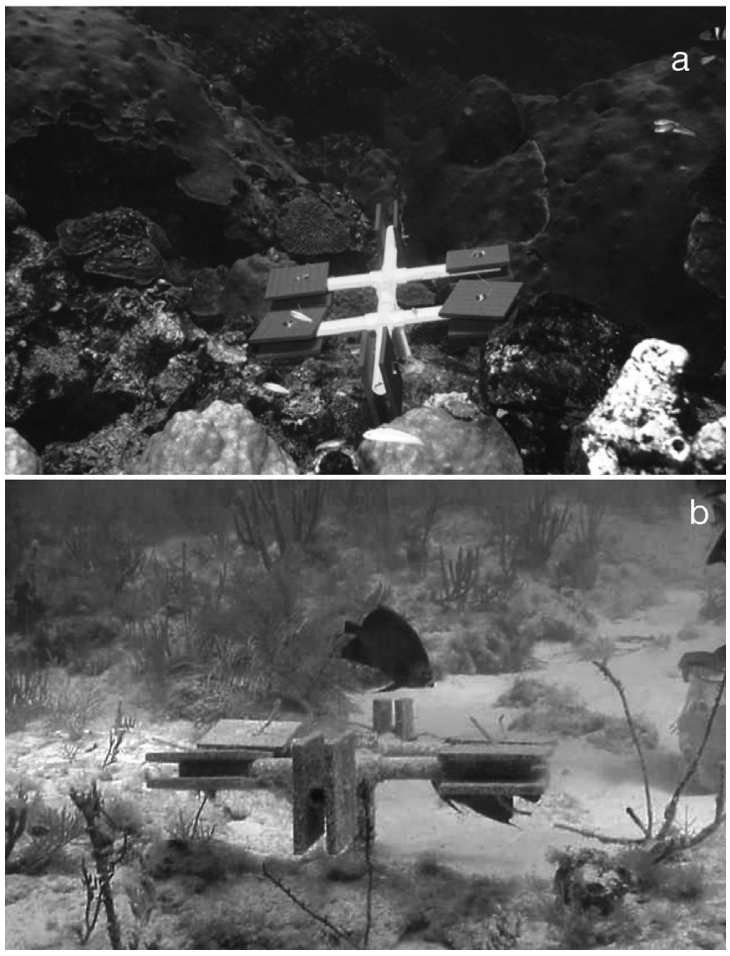

Fig. 3. Recruitment array illustrating plate orientation and habitat typical of study sites at (a) FGB and (b) FK

Depth appears to influence juvenile and recruit abundance (Chiappone \& Sullivan 1996, Smith 1997, but see Edmunds et al. 2004). To determine whether depth could contribute to differences in recruitment rates between the FGB (minimum $20 \mathrm{~m}$ reef depth) and the FK (minimum reef depths $<10 \mathrm{~m}$ ), arrays were placed at a shallow site $(10 \mathrm{~m})$ and a deep site $(\sim 24 \mathrm{~m})$ at Tennessee Reef (FK). Differences in recruitment between deep and shallow sites at Tennessee Reef would suggest that depth could contribute to differences in recruitment patterns between the FGB and the FK.

Settlement preference of coral larvae based on plate orientation (horizontal or vertical) and texture (grooved or smooth) imposes additional variables in analyzing recruitment patterns (e.g. Rogers et al. 1984, Baggett \& Bright 1985, Smith 1997). Our experimental design was unbalanced with regard to these variables (8 plates oriented horizontal and 4 vertical to the reef substrate with grooved side facing out), precluding statistical analyses to evaluate variance of these variables. To test the $H_{0}$ of equivalent recruitment rates across sites, location and year, spatial and temporal variation of the number of recruits per array (log transformed), rather than recruits per plate, were statistically analyzed to exclude variance due to plate orientation and texture. Statistical analyses were conducted using STATISTICA (version 5.1, StatSoft). Experimental design was a nested ANOVA with recruitment year as a repeated measure. 
Table 2. Deployment and sampling of recruitment plates at each site. Plates were sampled once during 2001-2002 due to low numbers of scleractinian recruits collected in the fall of 2000. With regard to the timing of deployment and sampling, note that Caribbean brooding species generally release larvae from April to June and mass spawning of broadcasting species is generally from July to September (reviewed in Richmond \& Hunter 1990, Szmant 1991, McGuire 1998)

\begin{tabular}{|c|c|c|c|c|c|c|}
\hline \multirow[t]{2}{*}{ Location } & \multirow{2}{*}{$\begin{array}{l}\text { No. arrays } \\
\text { (plates) }\end{array}$} & \multicolumn{2}{|c|}{$2000-2001$} & \multirow{2}{*}{$\begin{array}{c}2001-2002 \\
\text { No. recruits } \\
\text { collected }\end{array}$} & \multicolumn{2}{|c|}{ Total } \\
\hline & & $\begin{array}{l}\text { No. recruits } \\
\text { collected }\end{array}$ & $\begin{array}{l}\text { No. recruits } \\
\text { collected }\end{array}$ & & No. recruits & $\begin{array}{l}\text { No. arrays } \\
\text { (plates) }\end{array}$ \\
\hline \multicolumn{7}{|c|}{ Flower Garden Banks (FGB) ${ }^{\mathrm{a}}$} \\
\hline West FGB & $3(36)$ & 222 & 10 & 280 & 512 & $6(72)$ \\
\hline East FGB & $3(36)$ & 471 & 36 & 1185 & 1692 & $6(72)$ \\
\hline Total & $6(72)$ & 693 & 46 & 1465 & 2204 & $12(144)$ \\
\hline \multicolumn{7}{|l|}{ Florida Keys $(\mathrm{FK})^{\mathrm{b}}$} \\
\hline Carysfort Reef & $3(36)$ & 4 & 2 & 5 & 11 & $6(72)$ \\
\hline Tennessee Reef $(\sim 10 \mathrm{~m})$ & $3(36)$ & 7 & 4 & 10 & 21 & $6(72)$ \\
\hline Tennessee Reef $(\sim 24 \mathrm{~m})$ & $3(36)$ & 3 & 0 & 6 & 9 & $6(72)$ \\
\hline American Shoal & $3(36)$ & 50 & 7 & 118 & 175 & $6(72)$ \\
\hline Dry Tortugas & $3(36)$ & 7 & 1 & 2 & 10 & $6(72)$ \\
\hline Total & $15(180)$ & 71 & 14 & 141 & 226 & $30(360)$ \\
\hline
\end{tabular}

\section{RESULTS}

\section{Genetic method of species identification}

\section{Determining species-specific RFLP patterns}

Conspecific adult colonies always exhibited identical RFLP patterns (data not shown). Of the 29 adult species screened, 12 unique COI-RFLP patterns were useful for identification of coral recruits (Fig. 4). Because some species possessed identical COI sequences (Table 1), not all species could be distinguished using this gene region. Initial digestion with HaeIII resolved 7 distinct species and groups of closely related species with identical COI sequences (Fig. 4). Subsequent digestion of the Porites spp. group with TaqI distinguished Porites astreoides from 3 other Porites spp., and digestion with MseI revealed COI-RFLP differences among families Faviidae/ Mussidae (except Solenastrea bournoni), Meandrinidae and Siderastreidae. Despite COI sequence differences, species within the suborder Faviina and family Siderastreidae could not be fully resolved using this method. Because variable nucleotide sites distinguishing these species were not amenable to digestion with readily available restriction enzymes, further COI-RFLP analysis was not useful and sequencing of this COI region will be necessary to distinguish these species. All other species that could be genetically distinguished using this gene region (i.e. those that possessed distinct COI nucleotide sequences) were resolved with the initial HaeIII digestion (except the Porites group).
Identification of coral recruits

By compiling the results of the 3 COI-RFLP patterns for each species, the identification of unknown recruits was deduced to species or a limited number of possible species (Fig. 4). To identify recruits most efficiently, all recruits were initially digested with HaeIII. Those determined to be Porites spp. (other than P. porites) were subsequently digested with TaqI in order to identify $P$. astreoides recruits.

COI-RFLP analysis of 1333 recruits confirmed visual identification as genus Agaricia or Porites and allowed further resolution to species or groups of species (Table 3). There was no instance in which the morphologically based genus identification was inconsistent with the genetically based identification. Agaricia agaricites/A tenuifolia was numerically dominant on all recruitment plates (84.1\%), followed by Porites astreoides $(12.2 \%)$. Congeners of these species were extremely rare $(<0.2 \%)$. Of the 46 unidentified recruits (generally too small [ 1 to $2 \mathrm{~mm}$ diameter] for visual identification), 25 were determined to be A. agaricites/A. tenuifolia based on genetic identification. For our population genetic study, further identification (via sequencing) of the 21 unidentified recruits remaining was not necessary and was not conducted.

DNA of several recruits exhibited extra bands in the digestion gels. For example, recruits displayed the typical Agaricia species pattern when digested with HaeIII, but additional bands were also present (data not shown). When adding the molecular weights of 


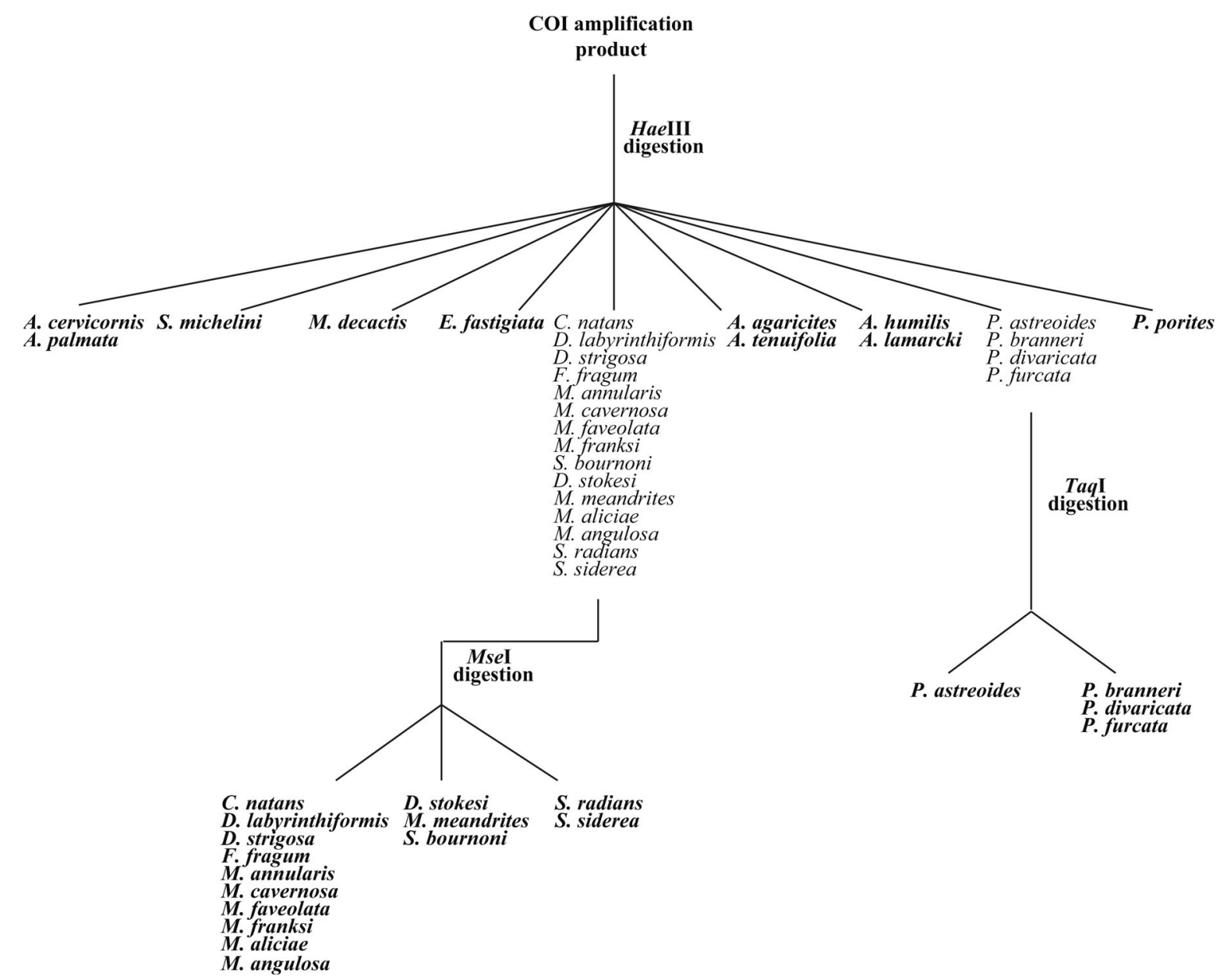

Fig. 4. Summary of digestion results and strategy used to identify Caribbean scleractinian recruits from COI-RFLP of adult samples. Species in bold indicate final species identification or species groups that could not be further resolved with COI-RFLP analysis. See Table 1 for genus names

these bands, the result is a much larger size than the expected 705 bp COI fragment. Because only one band of the expected size was observed prior to digestion, these bands are likely from a second PCR product (the same size as the coral DNA amplification) from another organism. The primers used in the PCR are universal and amplify a variety of organisms with a similar amplicon size (Folmer et al. 1994). DNA from zooxanthella cultures amplified and produced different RFLP patterns from corals (data not shown). As these extra bands are exhibited only in recruits and not in adults, zooxanthella DNA is not the likely source of these bands. During removal of recruits from the recruitment plates, tissue from
Table 3. Visual and genetic identification of scleractinian recruits from the FGB and the FK. Numbers in parentheses indicate number of recruits from the FGB identified both visually and genetically. Remaining recruits were visually identified only

\begin{tabular}{|c|c|c|c|c|}
\hline \multirow[t]{2}{*}{ Species } & \multicolumn{2}{|c|}{ FGB } & \multicolumn{2}{|c|}{ FK } \\
\hline & Visual & Genetic & Visual & Genetic \\
\hline Agaricia-like & 2171 (1074) & & 48 & \\
\hline A. agaricites/A. tenuifolia & & 1073 & & 48 \\
\hline A. lamarcki/A. fragilis & & 1 & & 0 \\
\hline Porites-like & 132 & & 33 & \\
\hline P. astreoides & & 130 & & 33 \\
\hline P. porites & & 1 & & 0 \\
\hline P. divaricata/P. furcata/P. branner & & 1 & & 0 \\
\hline Unidentified & 20 & & 26 & \\
\hline A. agaricites/A. tenuifolia ${ }^{\mathrm{a}}$ & & 2 & & 23 \\
\hline Unidentified & & 18 & & 3 \\
\hline
\end{tabular}


adjacent red calcareous algae or green filamentous algae may have been transferred, preserved and extracted with coral tissue. Due to the small size of the recruits, the proportion of coral DNA may be similar to that of any contaminating organism, thus both may amplify during PCR. In instances where extra bands were present in addition to an unambiguous coralspecific pattern, extra bands were disregarded.

\section{Recruitment arrays}

Recruitment was significantly greater at the FGB than at the FK ( $\mathrm{p}=0.0001$; Table 4: Region). Within both the FGB and FK, recruitment varied spatially among sites ( $p=0.000$; Table 4: Site) but did not vary on a temporal scale ( $p=0.397$; Table 4: Year). The East FGB exhibited higher recruitment rates than the West FGB; however, these differences were not significant (Fig. 5). American Shoal (AS) yielded significantly greater numbers of recruits relative to other FK reefs including DT (Fig. 5). Shallow and deep sites at Tennessee Reef yielded similarly low numbers of recruits over both years (Fig. 5).

Although recruitment also varied temporally, with a greater number of recruits during 2001 to 2002 at the FGB and AS (Fig. 5), this trend was not significant
(Table 4). East FGB yielded more than twice the number of recruits in 2001 to 2002 than in the previous year. There was also no significant interaction between regions and years or between study sites and years (Table 4).

Overall, 2430 recruits ranging from 1 to $10 \mathrm{~mm}$ in diameter (data not shown) were observed on recruitment plates, with the vast majority classified as Agaricia-like or Porites-like based on the initial visual inspection (Table 3). Due to the extraordinary number of recruits at the FGB, only 1074 of the 2171 recruits were subjected to genetic analysis, and identifications of the remaining 1097 recruits were based on visual inspection alone (Table 3).

Table 4. Spatio-temporal analysis (ANOVA) of scleractinian recruitment during 2000-2001 and 2001-2002 at FGB and FK. Error term represents 3 arrays at each site, ns: not significant $(\mathrm{p}>0.05),{ }^{* *}: \mathrm{p}<0.001$

\begin{tabular}{|lrrc|}
\hline Variance source & df & $F$ & $\mathrm{p}$ \\
\hline Region & 1 & 210.11 & ${ }^{* *}$ \\
Site & 6 & 45.17 & ${ }^{* *}$ \\
Year $(\log )$ & 1 & 0.77 & $\mathrm{~ns}$ \\
Region $\times$ Year $(\log )$ & 1 & 1.57 & $\mathrm{~ns}$ \\
Site $\times$ Year $(\log )$ & 6 & 1.71 & $\mathrm{~ns}$ \\
Error & 13 & & \\
\hline
\end{tabular}

\begin{tabular}{|c|c|c|c|c|c|c|c|c|c|}
\hline \multirow{4}{*}{$500-$} & \multirow[t]{4}{*}{1185} & & West FGB & East FGB & $\begin{array}{c}\text { Carysfort } \\
\text { Reef }\end{array}$ & $\begin{array}{c}\text { Tennessee } \\
\text { Reef }(10 \mathrm{~m})\end{array}$ & $\begin{array}{c}\text { Tennessee } \\
\text { Reef }(\sim 24 \mathrm{~m})\end{array}$ & $\begin{array}{c}\text { American } \\
\text { Shoal }\end{array}$ & $\begin{array}{c}\text { Dry } \\
\text { Tortugas }\end{array}$ \\
\hline & & LSD & $\mathrm{C}$ & $\mathrm{C}$ & A & A & A & B & $\mathbf{A}$ \\
\hline & & Tukey HSD & B, C & $\mathrm{C}$ & A & A & $\mathbf{A}$ & B & $\mathbf{A}$ \\
\hline & & Scheffe & $\mathrm{B}, \mathrm{C}$ & $\mathrm{C}$ & A & $\mathbf{A}$ & A & B & A \\
\hline
\end{tabular}

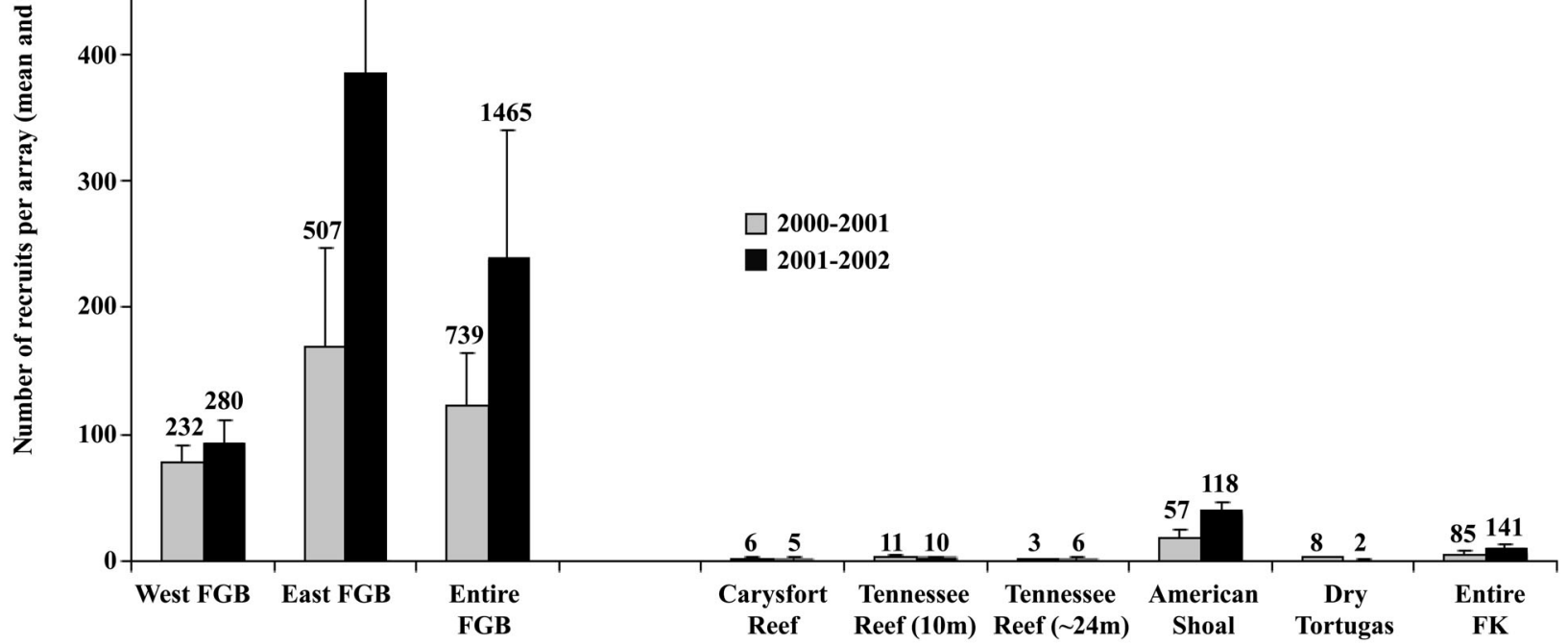

Flower Garden Banks

Florida Keys

Fig. 5. Spatial and temporal variation in scleractinian recruits per array (12 recruitment plates each) observed at FGB and FK from 2000-2001 and 2001-2002. Mean and SE derived from 3 arrays per site. Numbers above bars indicate actual number of recruits per site. Insert: statistical post-hoc comparisons revealed significant differences in recruitment among sites $(p=0.0001)$ 


\section{DISCUSSION}

Monitoring recruitment rates at sites in the FGB and FK yielded over 2400 scleractinian recruits, with the vast majority of these occurring at the FGB sites. Most of the recruits could be visually identified to the genus level, however, genetic methods resolved classification of these recruits to species, demonstrating the value to this approach. Genetic identification of recruits using COI-RFLP analysis is a simple method to rapidly identify newly settled recruits (as small as 1 to $2 \mathrm{~mm}$ ) of common Caribbean coral species. Thus, although visual inspection resulted in accurate identification of Agaricites and Porites recruits to the genus level, multiple species within these genera (i.e. A. fragilis/A. lamarcki, $P$. porites and $P$. branneri/P. divaricata/P. furcata) do occur in the study areas, albeit infrequently. Prior to genetic analysis, it was unknown which species of these genera would be represented on the recruitment plates, and in what proportions. Although the COI-RFLP method of identifying the rare faviid recruits may not be more effective than identification through morphological means, species identification can be resolved via sequencing of the COI gene. Thus, the genetic method of identification is often more useful than morphological methods to address speciesspecific recruitment issues. Depending on the purpose of the study (e.g. population genetics and paternity analysis versus generalized recruitment patterns), genetic identification of recruits to species level may or may not be necessary.

In addition, the ability to conduct additional genetic analyses on these recruits is an enormous advancement for the acquisition of new perspectives on the ecology and evolution of scleractinians. Implementation of advances in molecular and genomic technology to address issues relating to marine ecology (e.g. Ryan \& Finnerty 2003, Hofmann et al. 2005) is becoming more prevalent and will be central to future coral research. Using genetic methods to identify scleractinian recruits facilitates the investigation of paternity, connectivity and larval sources, in addition to ontogenetic and developmental research on natural populations.

Use of this genetic identification tool to analyze recruits at the FGB and the FK provided greater taxonomic resolution than was obtained by morphology alone. The vast majority of recruits in this study were genetically identified as Agaricia agaricites (or A. tenuifolia) and Porites astreoides. Although the COIRFLP analysis cannot discriminate between A. agaricites and $A$. tenuifolia, most if not all recruits matching this COI-RFLP pattern were assumed to be A. agaricites based on adult abundances (A. tenuifolia was not observed at any study site). Recruitment at the FGB and FK during 2000 to 2001 and 2001 to 2002 was consistent, in terms of genus dominance, with previous recruitment studies at these locations and throughout the Caribbean (Rylaarsdam 1983, Rogers et al. 1984, Baggett \& Bright 1985, Smith 1997, Kojis \& Quinn 2001). Direct comparisons of recruitment rates from this study to other recruitment studies are difficult to make due to differences in substrates and length of deployment; however, recruitment rates at the FGB observed in this study (4.8 to 54.8 recruits per plate) were similar to rates from a comparable analysis at this location (0 to 47.0 recruits per plate; Baggett \& Bright 1985). Scleractinian recruitment at the FK $(<0.1$ to 3.3 recruits per plate) was less than previously observed at the FK (Conch Reef; $\sim 3$ to 50 recruits per plate; Smith 1997) and Barbados (0.8 to 12.7 recruits per plate; Tomascik 1991) over a decade ago.

Significantly higher recruitment at the FGB relative to the FK may have been due to several factors, including differences in potential larval sources, environmental conditions (i.e. depth and water temperature), live coral coverage, post-settlement mortality and general reef health. Because dispersal of brooded larvae is expected to be local (e.g. Carlon \& Olson 1993, Tioho et al. 2001, Heltzel \& Babcock 2002, Nishikawa et al. 2003), recruitment of brooding corals at both locations suggests that differences in the local adult populations (e.g. population sizes and live coral coverage) are primary factors in the disparity of recruitment rates. Live coral coverage is high at the FGB (30 to $>60 \%$ ) with 'near excellent' habitat conditions (Lang et al. 2001). Meanwhile, coral populations in the FK have been in decline over the past 2 decades (e.g. Gardner et al. 2003) with coral cover ranging from 2 to $20 \%$ (Miller et al. 2000). As such, arrays at the FGB were adjacent to numerous large coral colonies, whereas large colonies were sparse at FK sites (see Fig. 3). High post-settlement mortality may contribute to low levels of scleractinian recruitment observed at the FK (Smith 1997, Miller et al. 2000); however, juvenile mortality data were not available for the FGB for comparison. Similarly low numbers of recruits at both the Tennessee Reef shallow and deep sites indicated that depth was not a primary influence on recruitment at this reef, and was not a likely explanation for recruitment differences between the FGB and the FK.

Recruitment at AS was significantly higher than at any other FK site, including DT. Compared to other study sites in the FK, there were no obvious differences in coral cover, environmental conditions or placement of recruitment plates relative to adult corals at AS that may have contributed to the observed recruitment difference. AS is located at the western end of the FK reef 
tract, and is exposed to influences of the Pourtales Gyre multiple times throughout the year (Lee et al. 1994, Fig. 1b) including during periods of coral reproduction. This gyre, which can be maintained for up to $1 \mathrm{mo}$, is responsible for recirculation patterns over the lower Keys and creates a mechanism for larval retention. Reefs in the middle and upper Keys and DT do not experience similar recirculation patterns (Lee et al. 1994), thus larvae may not be retained to the same extent as at AS.

In light of heightened concern over the deterioration of coral reefs throughout the world, understanding influences and patterns of coral recruitment will be central to monitoring the health of these reefs. Once able to genetically identify species of recruits and apply additional techniques to ascertain their larval origin and genetic relatedness, researchers can begin to obtain data that are fundamental to understanding this important life history stage of reefbuilding corals.

Acknowledgements. We thank the Florida Keys National Marine Sanctuary and the Flower Garden Banks National Marine Sanctuary for permission to collect scleractinian samples. Special thanks to K. Amo-Mensah, D. Akselrod, T. Bates, I. Baums, P. Biber, V. Bisen, M. Boller, L. Chan, H. Dienes, J. DeBose, N. DuPree, A. Hannes, L. Horn, C. Humphries, N. Kirk, P. Lane, C. Lewis, J. Lin, S. Maenner, B. Mitri, A. Moulding, L. Nti, C. Rigaud, L. Rutten, S. Santos, D. Swanson and J. Weaver for collection and laboratory assistance. Thanks to the staff of Keys Marine Lab for logistical support and to the crews of the MV 'Spree' and RV 'Big Moe'. We thank M. Barbeitos and $\mathrm{H}$. Lasker for analytical assistance, D. Brazeau, M. Hellberg, H. Lasker and D. Taylor for comments on the manuscript and J. Stamos for assistance with figures. This research was supported by NOAA's National Undersea Research Program (M.A.C. 2000-15; M.A.C. and J. Ault 200212), the National Science Foundation (M.A.C. OCE-95-30057 and OCE-99-07319).

\section{LITERATURE CITED}

Babcock RC, Baird AH, Piromvaragorn S, Thomson DP, Willis BL (2003) Identification of scleractinian coral recruits from Indo-Pacific reefs. Zool Stud 42:211-226

Baggett LS, Bright TJ (1985) Coral recruitment at the East Flower Garden Reef (Northwestern Gulf of Mexico). Proc 5th Intl Coral Reef Cong 4:379-384

Baird AH, Babcock RC (2000) Morphological differences among three species of newly settled pocilloporid coral recruits. Coral Reefs 19:179-183

Bright TJ, Kraemer GP, Minnery GA, Viada ST (1984) Hermatypes of the Flower Garden Banks, northwestern Gulf of Mexico: a comparison to other western Atlantic reefs. Bull Mar Sci 34:461-476

Carlon DB, Olson RR (1993) Larval dispersal distance as an explanation for adult spatial pattern in two Caribbean reef corals. J Exp Mar Biol Ecol 173:247-263

Chiappone M, Sullivan KM (1996) Distribution, abundance and species composition of juvenile scleractinian corals in the Florida Reef Tract. Bull Mar Sci 58:555-569
Coffroth MA, Lasker HR, Diamond ME, Bruenn JA, Bermingham E (1992) DNA fingerprints of a gorgonian coral: a method for detecting clonal structure in a vegetative species. Mar Biol 114:317-325

Edmunds PJ, Bruno JF, Carlon DB (2004) Effects of depth and microhabitat on growth and survivorship of juvenile corals in the Florida Keys. Mar Ecol Prog Ser 278:115-124

Fisk DA, Harriott VJ (1990) Spatial and temporal variation in coral recruitment on the Great Barrier Reef: implications for dispersal hypotheses. Mar Biol 107:485-490

Folmer O, Black M, Hoeh W, Lutz R, Vrijenhoek R (1994) DNA primers for amplification of mitochondrial cytochrome $c$ oxidase subunit I from diverse metazoan invertebrates. Mol Mar Biol Biotechnol 3:294-299

Gardner TA, Cote IM, Gill JA, Grant A, Watkinson AR (2003) Long-term region-wide declines in Caribbean corals. Science 301:958-960

Glassom D, Zakai D, Chadwick-Furman NE (2004) Coral recruitment: a spatio-temporal analysis along the coastline of Eilat, northern Red Sea. Mar Biol 144:641-651

Harriott VJ (1999) Coral recruitment at a high latitude Pacific site: a comparison with Atlantic reefs. Bull Mar Sci 65: 881-891

Harriott VJ, Fisk DA (1988) Recruitment patterns of scleractinian corals: a study of three reefs. Aust J Mar Freshw Res 39:409-416

Heltzel PS, Babcock RC (2002) Sexual reproduction, larval development and benthic planulae of the solitary coral Monomyces rubrum (Scleractinia: Anthozoa). Mar Biol 140:659-667

Hofmann GE, Burnaford JL, Fielman KT (2005) Genomicsfueled approaches to current challenges in marine ecology. Trends Ecol Evol 20:305-311

Kojis BL, Quinn NJ (2001) The importance of regional differences in hard coral recruitment rates for determining the need for coral restoration. Bull Mar Sci 69:967-974

Lang JC, Deslarzes KJP, Schmahl GP (2001) The Flower Garden Banks: remarkable reefs in the NW Gulf of Mexico. Coral Reefs 20:126

Lee TN, Clarke ME, Williams E, Szmant AF, Berger T (1994) Evolution of the Tortugas Gyre and its influence on recruitment in the Florida Keys. Bull Mar Sci 54:621-646

McGuire MP (1998) Timing of larval release by Porites astreoides in the northern Florida Keys. Coral Reefs 17: 369-375

Miller MW, Weil E, Szmant AM (2000) Coral recruitment and juvenile mortality as structuring factors for reef benthic communities in Biscayne National Park, USA. Coral Reefs 19:115-123

Nishikawa A, Katoh M, Sakai K (2003) Larval settlement rates and gene flow of broadcast spawning (Acropora tenuis) and planula brooding (Stylophora pistillata) corals. Mar Ecol Prog Ser 256:87-97

Ogden JC (1997) Marine managers look upstream for connections. Science 278:1414-1415

Palumbi SR (2003) Population genetics, demographic connectivity, and the design of marine reserves. Ecol Appl 13:S146-S158

Rezak R, Bright TJ, McGrail DW (1985) Reefs and banks of the Northwestern Gulf of Mexico: their geological, biological, and physical dynamics. Wiley Interscience, New York

Richmond RH, Hunter CL (1990) Reproduction and recruitment of corals: comparisons among the Caribbean, the Tropical Pacific, and the Red Sea. Mar Ecol Prog Ser 60: 185-203

Roberts CM (1997) Connectivity and management of Caribbean coral reefs. Science 278:1454-1457 
Rogers CS, Fitz HC, Gilnack M, Beets J, Hardin J (1984) Scleractinian coral recruitment patterns at Salt River Submarine Canyon, St-Croix, United States Virgin Islands. Coral Reefs 3:69-76

Ryan JF, Finnerty JR (2003) CnidBase: The cnidarian evolutionary genomics database. Nucleic Acids Res 31: 159-163

Rylaarsdam KW (1983) Life histories and abundance patterns of colonial corals on Jamaican reefs. Mar Ecol Prog Ser 13: $249-260$

Sale PF, Kritzer JP (2003) Determining the extent and spatial scale of population connectivity: Decapods and coral reef fishes compared. Fish Res 65:153-172

Seutin G, White BN, Boag PT (1991) Preservation of avian blood and tissue samples for DNA analyses. Can J Zool 69: $82-90$

Shanks AL, Grantham BA, Carr MH (2003) Propagule dispersal distance and the size and spacing of marine reserves. Ecol Appl 13:S159-S169

Shearer TL (2004) Reef connectivity: Genetic analysis of recruitment and gene flow among Caribbean scleractinian corals. PhD dissertation, University at Buffalo, Buffalo, NY

Shearer TL, Van Oppen MJH, Romano SL, Worheide G (2002) Slow mitochondrial DNA sequence evolution in the Anthozoa (Cnidaria). Mol Ecol 11:2475-2487

Shearer TL, Gutiérrez-Rodríguez C, Coffroth MA (2005)

Editorial responsibility: Otto Kinne (Editor-in-Chief), Oldendorf/Luhe, Germany
Generating molecular markers from zooxanthellate cnidarians. Coral Reefs 24:57-66

Shulman MJ, Bermingham E (1995) Early life histories, ocean currents, and the population genetics of Caribbean reef fishes. Evolution 49:897-910

Smith SR (1997) Patterns of coral settlement, recruitment and juvenile mortality with depth at Conch Reef, Florida. In: Lessios HA, Macintyre IG (eds) Proc 8th Intl Coral Reef Symp 2:1197-1202

Snell TL (1997) Morphological and genetic variation in the scleractinian coral, Montastraea cavernosa. MS thesis, Louisiana State University, Baton Rouge, LA

Snell TL, Foltz DW, Sammarco PW (1998) Variation in morphology vs conservation of a mitochondrial gene in Montastraea cavernosa (Cnidaria, Scleractinia). Gulf Mex Sci 16:188-195

Szmant AM (1991) Sexual reproduction by the Caribbean reef corals Montastraea annularis and M. cavernosa. Mar Ecol Prog Ser 74:13-25

Tioho H, Tokeshi M, Nojima S (2001) Experimental analysis of recruitment in a scleractinian coral at high latitude. Mar Ecol Prog Ser 213:79-86

Tomascik T (1991) Settlement patterns of Caribbean scleractinian corals on artificial substrata along a eutrophication gradient, Barbados, West-Indies. Mar Ecol Prog Ser 77: 261-269

Submitted: March 15, 2005; Accepted: August 4, 2005

Proofs received from author(s): December 5, 2005 